\title{
Reseña. Gustavo Gac-Artigas, Y todos éramos actores, un siglo de luz y sombra. USA: Nuevo Espacio, 2015.
}

Adentrarse en las páginas de $Y$ todos éramos actores, un siglo de luz y sombra resulta obligada lectura para todo aquel que quiera asomarse al proceso sociológico e historiográfico de las generaciones y política durante uno de los periodos sociales más aciagos de Latinoamérica: la problemática política de Chile y su paradigmática generación revolucionaria de mil novecientos sesenta y ocho. La novela nos presenta un enfoque de lo generacional vinculado a cultura y subjetividad política, con marcada influencia del filósofo Karl Mannheim y sus conceptos sobre juventud y generaciones. Es una narración donde el título mismo introduce a la temática recordándonos el concepto aristotélico del Zoon politikón y la humana necesidad de relacionarse políticamente creando sociedades, pero sobre todo organizando la vida en ciudades-estado, recordándonos que es el homo sapiens el único por cierto con la capacidad de expresarse mediante un lenguaje inteligible. En este contexto Gac-Artigas sumerge al lector en los avatares cuasi epopéyicos de una troupe de théâtre que en su afán de expandir la toma de conciencia recorre el mundo huyendo del militarismo desatado en persecución de todo lo que sonase a juventud liberadora. Porque su obra es como una mirada a la vida política y la geografía de América del Sur, su geografía, su 
flora y fauna vibrante, leerlo es lanzarse en la aventura creativa rica en asuntos y motivos para hacer un recorrido geográfico con descripciones abundantes por Chile, Perú y Colombia.

Gac-Artigas describe en $Y$ todos éramos actores un siglo de luz y sombra con influencia del criollismo, una obra casi heteroglósica, una narración costumbrista de orientación político social. Con un estilo de escribir superrealista, pues más que hablar de la realidad o del paisaje se ocupa de describir lo que las personas llevan por dentro, de sus sentires y pesares así como de sus filias políticas y las problemáticas vividas a raíz de sus procederes en consecuencia. Adentrarse en sus páginas requiere estar consciente y lúcido -al menos en cierta disposición para asumir la conciencia en cuanto a la realidad sociopolítica no tan solo de Chile y su proceso revolucionario sino de la América Latina y el mundo entero. La lectura de Y todos éramos actores un siglo de luz y sombra es de esas lecturas que sacuden la conciencia en la medida que el lector se interna en los avatares de lo que bien puede considerarse una aventura epopéyica, orilla a la asunción de la conciencia o a la negación de la misma, pudiendo perderse en el uso del libre albedrío a través de los medios de difusión y la alharaca política; tal como lo propone al narrarnos en la primera cuarta parte de su novela, cuando relata la historia de las dos hermanas colombianas hijas de la violencia y su escape dramático: cuando una de ellas decide subir a los escenarios mientras la otra "[...] comenzó a caminar hacia la locura para escapar de la misma. Asimismo contempla la opción de [...] quedarse en el decorado, en el ruido de los tambores [...] protegerse en historias venidas de lejos, proyectadas en las nubes y protagonizadas por otros actores. [Para terminar afirmando] que eso no es entrar en la historia".

En la lectura de Y todos éramos actores de Gac-Artigas nos encontramos ante una narración cronológica que consta de siete capítulos y veintiocho cantos con un narrador interno homodiegético que parece mecerse en una relación atemporal, en una mezcla de historia y mitología, con tintes surrealistas. De los siete capítulos, los primeros cuatro podríamos decir que son formativos para la 
troupe en cuanto que relatan la travesía del grupo y la toma de conciencia asumida en su contacto con los grupos mineros, de su actuación en los gallineros de Chile, del contacto con los grupos europeos de mayo del 68 y Latinoamérica de los inicios de los setentas, desde su perspectiva de actuación siendo el protagonista víctima y testigo al enfrentar persecución política. La narrativa de los últimos tres capítulos nos llena de la vivencia del exilio en Francia, Alemania y Bulgaria desde el encarcelamiento hasta el desenlace en tierras andinas con el despropósito de la negativa de acceso a Chile en vano intento de consumar el periplo.

$Y$ todos éramos actores no es una narración fácil de asumir, a juzgar por lo enciclopédico de su carácter, por la gala de conocimientos con que despliega la travesía internándose en un laberinto de descripciones geográficas de Chile, Bolivia, Perú, Ecuador y Colombia enriquecido con una relación de flora y fauna, usos y costumbres y reflexiones sobre el quehacer teatral. En la opinión de Edith Grossman vertida en cartas personales, la narrativa de Gac-Artigas "Impresiona [por] el juego temporal-la interpretación de lo histórico, lo mitológico, y lo surreal. Escribe más parecido a un poema épico que a una novela”. Los dramas de G-Artigas tienen un contenido ideológico como si fuera un postulado de Bertolt Brecht pero dentro de un superrealismo del nuevo mundo, con esa capacidad de crear dos espacios simultáneos, el de la realidad externa y el de lo meramente subjetivo recordando la temática de algunos escritores donde el acoso juega un papel fundamental, aunque sin cumplirse en un tiempo circular, Gac Artigas parece mecerse en una cronología atemporal en la que se plasma los non siempre venturosos avatares de un director de teatro y su troupe a quien el acoso político y el exilio les lleva a recorrer el mundo para concretar sus esfuerzos concientizadores mediante puestas en escenas de un teatro del pueblo. Para recordarnos en medio de una abundante intertextualidad en materia teatral y cinematográfica como La Madre de Brecht, Los que van quedando en el camino de Isidora Aguirre y los grandes del teatro como Jerzy Grotowski [que] la mejor herramienta de un actor es su propio cuerpo, "y [que] todos éramos actores" y 
seguiremos siendo actores de nuestra propia obra teatral representativa del momento histórico que nos tocó vivir. Proporciona nombres -nos introduce a- los fundadores del teatro, de cómo se formó un puente literalmente hablando "entre escenarios y el público, entre las voces y la vida, entre la historia y el camino sembrado de peligros que la cruza". Del relato de las presentaciones teatrales como herramienta poética y de toma de conciencia, del sufrimiento de los actores, de aquellos guerrilleros que atravesaban el proceso de represión militar sumándonos a recorrer la historia de la persecución política, los refugios desde donde observaban los desplazamientos de los militares. "De cómo en los guerrilleros detenidos, de sus hombros encorvados, de sus cabezas gachas se elevaba una dignidad que sobrevolaba los fusiles [...]”.

En términos generales, Gac-Artigas en su narrativa nos propone el teatro como ejercicio reflexivo a través de una relectura del Chile post Allende y su movimiento libertario subversivo mediante la lectura meta histórica de un hecho fundacional en la historia de Latinoamérica. Aún de su estancia en la cárcel de Rancagua se desprende un análisis del concepto que nos refiere necesariamente a Jeremy Bentham y el modelo Panóptico de vigilancia cuando expresa que "La dimensión de la cárcel no interesa. Puede ocupar una manzana o un país, un país o una unión de países; puede ocupar, y ello sí es terrible, un individuo, su mente encarcelando su cuerpo o su cuerpo encarcelando su mente y de ese tipo de cárcel difícilmente se escapa". Así nos lleva de la mano de la historia de su amor por Chile, por los Andes describiéndose a sí mismo como parte integrante de un ecosistema político. Narra de cómo entró a ser observador partícipe de la historia de su patria de una manera casi inaudita e inaudible, paliativa de su soledad. De su cuasi inadvertida incorporación a las juventudes comunistas en Chile y de cómo fue a dar al Festival mundial de las juventudes en Bulgaria. Con la lectura de $Y$ todos éramos actores abordamos la intrahistoria de los ideales revolucionarios de un pueblo a través de sus grupos de teatro al mismo tiempo que nos acerca a la emblemática lucha ideológica del 68 desde Checoslovaquia, Alemania y Francia. Nos pone de manifiesto la necesidad de concientizar en el 
movimiento de los pueblos mineros, los habitantes de las ciudades, los obreros y estudiantes, amas de casa y el sentir del pueblo en general a través de un elemento único: el teatro. Proporciona nombres introduciéndonos a los fundadores del teatro; de cómo se formó un puente literalmente hablando "entre escenarios y el público, entre las voces y la vida, entre la historia y el camino sembrado de peligros que la cruza". Esta novela con tintes autobiográficos conduce al ineludible enfrentamiento con la realidad histórica, y con ello a un choque entre lo publicado y cómodamente permitido y la versión de los de a pie, los viajeros viandantes, los hombres de teatro. Y si bien de acuerdo a Morales Piña en Brevísima Relación de la Nueva Novela Histórica en Chile los escritores hispanoamericanos tienden a "imaginar la historia en el propósito de problematizar el discurso oficial con la finalidad de recusarlo, en un afán de suplir sus carencias a través de discursos alternativos", a Gustavo Gac-Artigas no le hace falta ficcionalizar grandemente el discurso histórico porque él mismo lo vivió y lo recrea en un discurso alternativo. Y todos éramos actores reúne un buen número de las características que de acuerdo a Menton definen la nueva novela histórica de la América Latina: presenta la subordinación histórica en distintos grados haciendo la reproducción mimética de cierto periodo histórico chileno-el gobierno de Allende-y el posterior golpe de Estado, haciendo la distorsión consciente de la historia mediante numerosas alusiones de tipo autobiográfico, recurriendo a la funcionalización de personajes históricos, al mismo tiempo que introduce comentarios del narrador sobre el proceso de creación. Si bien es cierto $Y$ todos éramos actores, un siglo de luz y sombra se encuentra anclada en un momento histórico aciago y amargamente olvidado de la historia latinoamericana: la lucha del Chile libertario, nos arroja desde la sombras - como en el teatroreflectores sobre la memoria activa de los de a pie, la voz de los sin voz, aquellos que como dijera Aínsa "la historia ha negado, silenciado o perseguido", los que 
nunca pudieron regresar por aparecer registrados en una lista negra y sin embargo permanecieron como dijera el poema de Alberti con "Chile en el corazón" pero sin poder volverlo a pisar. 